\title{
Effect of Oral Administration of Pleuroteus Tuber-Regium Extract on Growth, Serum Metabolites and Histomorphological Changes in Growing Rabbits
}

\section{Suliat A. Salami ${ }^{1 *}$, Adekunle B. Rowaiye ${ }^{1}$, Samuel K. Ogoina ${ }^{2}$, Ayuba A. Amos ${ }^{2}$, Solomon O. ONI $^{2}$, Titilayo M. Asala ${ }^{1}$, Doofan Bur ${ }^{1}$, Terna H. David ${ }^{2}$}

${ }^{1}$ National Biotechnology Development Agency, Federal Capital Territory Abuja, Nigeria; ${ }^{2}$ Bioresources Development Centre, Isanlu, Kogi State Nigeria.

\begin{abstract}
The effects of the oral administration of aqueous extract of Pleuroteus tuber-regium sclerotium (PTRSE) in drinking water on growth, serum metabolites and histomorphology parameters were examined using 72 crossbred growing rabbits. Eighteen rabbits each were allotted to 4 treatments with; 0, 500, 750 and $1250 \mathrm{mg}$ PTRSE per liter $(\mathrm{mg} / \mathrm{L})$ in drinking water per day. The experiment lasted for 60 days. Data collected were subjected to oneway analysis of variance (ANOVA). The results revealed an improvement in the live weight $(\mathrm{P}<0.01)$, weight gain (Linear (L), Quadratic $(\mathrm{Q})$ : $\mathrm{P}<0.01$ ), feed conversion ratio (L, $\mathrm{Q}: \mathrm{P}<0.01)$, water intake $(\mathrm{L}, \mathrm{Q}: \mathrm{P}<0.01)$ and extract intake ( $\mathrm{L}, \mathrm{Q}: \mathrm{P}<0.01)$ following increasing levels of PTRSE in drinking water. Oral administration of $750 \mathrm{mg} / \mathrm{L}$ PTRSE in drinking water resulted in reduced $(\mathrm{P}<0.01)$ serum total cholesterol, low-density lipoprotein, very lowdensity lipoprotein, creatinine and alkaline phosphatase; and increased cecal villi height ( $\mathrm{L}, \mathrm{Q}: \mathrm{P}<0.05)$ and apical width (Q:P <0.05). Pathological indicators suggested damages to hepatic tissues in rabbits on $1250 \mathrm{mg} / \mathrm{L}$ PTRSE. In conclusion, the oral application of $750 \mathrm{mg} / \mathrm{L}$ PTRSE in drinking water can improve the growth, cholesterol profile and absorptive capacity in growing rabbits without imposing any detrimental effect.
\end{abstract}

Keywords | Intestinal morphology, Mushroom extract, Pathology profile, Serum analytes

Received | March 26, 2021; Accepted | June 30, 2021; Published | August 15, 2021

*Correspondence | Suliat Adebola Salami, Bioentrepreneurship and Extension Services Department, National Biotechnology Development Agency, Airport Road, Lugbe Federal Capital Territory Abuja, Nigeria; Email: salami.suliata@pg.funaab.edu.ng

Citation | Salami SA, Rowaiye AB, Ogoina SK, Amos AA, Oni SO, Asala TM, Bur D, David TH (2021). Effect of oral administration of Pleuroteus Tuber-Regium extract on growth, serum metabolites and histomorphological changes in growing rabbits. Adv. Anim. Vet. Sci. 9(10): 1576-1584.

DOI | http://dx.doi.org/10.17582/journal.aavs/2021/9.10.1576.1584

ISSN (Online) | 2307-8316; ISSN (Print) | 2309-3331

Copyright (c) 2021 Salami et al. This is an open access article distributed under the Creative Commons Attribution License, which permits unrestricted use, distribution, and reproduction in any medium, provided the original work is properly cited.

\section{INTRODUCTION}

$\mathrm{I}_{\mathrm{n}}^{\mathrm{n}}$ West Africa, Pleurotus tuber-regium (PTR) is a mushroom specie of high economic value. It is in high demand for culinary, medicinal, and bioremediation purposes (Oyetayo, 2011). Of all the parts of PTR, greater interest is placed on the sclerotium amongst the indigenous people. Several researches (Huang et al., 2014; Nworu et al., 2014; Oghenemaro, 2017) have shown that PTR sclerotium has hematinic, immunostimulant, anticancer, anti-inflammatory, hypolipidemic, hepatoprotective, and antihyperglycemic properties. Previous study has also proven its ability to promote the growth of beneficial bacteria, inhibit the proliferation of harmful microbes, enhance immunity, and stimulate the growth and proliferation of the absorptive cells in the gut (Sethiya, 2016).

The nutraceutical and growth promoting potential of PTR has been largely attributed to its phytochemical constituents and significant amount of non-starch polysaccharides (e.g. $\beta$-glucan) found in its cell wall. Solvent extraction of raw plants is usually done to optimize the concentration of bioactive components (Aziz et al., 2003). However, researches have shown that the bioactivities of extract vary according to extraction methods used (Hayouni et al., 2007; 
Asif and Kaleem, 2018). Many bioactive compounds have been identified in mushroom extracts and are available for use as dietary supplements (Jyotika et al., 2013).

Given the broad spectrum of action, and reports of previous studies, (Vargas-Sánchez et al., 2017; Sohail et al., 2016) it can be inferred that different species of mushroom can play key roles in the nutrition of farm animals. They act as valuable source of nutrition and bioactive substances which has been linked to improved intestinal health, performance and health status of livestock. They can also serve as safe alternatives to antibiotic growth promoters. However, reports on the utilisation of PTR in rabbits are sparse. Hence this study was designed to investigate the effect of the aqueous extract of Pleuroteus tuber-regium sclerotium (PTRSE) and its effects on growth and some physiological and biochemical parameters in growing rabbits.

\section{MATERIALS AND METHODS}

\section{EXPERIMENTAL SITE}

This experiment was conducted at the Animal House of the Bioresources Development Centre Isanlu, Kogi State, Nigeria $\left(8^{\circ} 17^{\prime \prime} \mathrm{N} 5^{\circ} 50^{\prime \prime} \mathrm{E}\right)$. This lies in the tropical climate with average annual rainfall of $1100 \mathrm{~mm}$ and annual mean temperature of $34^{\circ} \mathrm{C}$ and $80 \%$ relative humidity.

\section{Pleuroteus tuber-REgiUm EXTRACT PREPARATION}

Indigenous edible Nigerian Pleurotus tuber-regium was sourced from the Bioresources Development Centre Isanlu, Kogi State, Nigeria. The sclerotia's dark brown skin was removed while the white tissue was cut into small pieces and pulverized $(>0.5 \mathrm{~mm})$ with a dry electric mill. An aqueous decoction of PTRSE was prepared according to the method described by Poonam et al. (2011). The PTR powder (PTRSP) was added into the water at a ratio of $1: 15 \mathrm{w} / \mathrm{v}$. The solution was allowed to cool and then filtered. The insoluble solids were separated by filtration through a muslin cloth. The extracts were then filtrated through Whatman No. 1 filter paper. The filtrate was concentrated and dried in a rotary evaporator (Equitron Roteva) maintained at $40^{\circ} \mathrm{C}$ and stored in air-tight containers at room temperature.

\section{Phytochemical SCREening of PTRSP AND PTRSE}

Samples of PTRSP and freshly prepared PTRSE were collected and screened for phytochemical constituents. Quantitative estimation of the total phenol was determined by the Folin-Ciocalteau reagent method as described by Malick and Singh (1980). $30 \mathrm{ml}$ PTR extract sample was added to $1.0 \mathrm{ml}$ of freshly diluted Folin-Ciocalteau reagent. Two grams of sodium carbonate dissolved in 100 $\mathrm{ml} 0.1 \mathrm{~N} \mathrm{NaOH}$ solution was then added to the mixture and mixed thoroughly. The test tubes were placed in a boiling water bath for exactly one min, the tubes were cooled and make up to a suitable volume. The absorbance was measured at $650 \mathrm{~nm}$ against a blank of distilled water using a spectrophotometer.

Flavonoid concentration was determined and expressed as $\mathrm{mg}$ of rutin equivalent (Helmja et al., 2007). $1 \mathrm{~g}$ of PTR extract was added to $1 \mathrm{ml}$ of $80 \%$ ethanol. Aliquot of 0.5 $\mathrm{ml}$ was added to the test tube containing $0.1 \mathrm{ml}$ of $10 \%$ aluminum nitrate, $0.1 \mathrm{ml}$ of $1 \mathrm{M}$ potassium acetate, and $4.3 \mathrm{ml}$ of $80 \%$ ethanol. The absorbance of the supernatant was measured at $415 \mathrm{~nm}$ after 40 minutes of incubation at room temperature. Alkaloid concentration was determined according to the procedure described by Harbone (1984). Five grams of the sample was weighed and dispersed in $10 \%$ acetic acid solution in ethanol to form a ratio of $1: 10$ (10\%). The mixture was allowed to stand for $4 \mathrm{~h}$ at $28^{\circ} \mathrm{C}$. It was later filtered using Whatman No. 42 grade of filter paper. The filtrate was concentrated to one quarter of its original volume by evaporation and treated with drop wise addition of concentrated aqueous $\mathrm{NH}_{4} \mathrm{OH}$ until the alkaloid was precipitated. The alkaloid precipitated in a weighed filter paper was washed with $1 \%$ ammonia solution and dried in the oven at $80^{\circ} \mathrm{C}$ The tannin content was determined using Folin Denis Reagent as described by Makkar et al. (1993). Suitable aliquots of the tannincontaining extract (initially: 0.05, 0.2 and $0.5 \mathrm{~mL}$ ) were pipetted in test tubes, the volume was made up to 1.00 $\mathrm{mL}$ with distilled water, then $2.5 \mathrm{~mL}$ of sodium carbonate reagent were added. Then the tubes were shaken and the absorbance was recorded at $725 \mathrm{~nm}$ after $40 \mathrm{~min}$.

\section{EXPERIMENTAL ANIMALS AND EXPERIMENTAL DESIGN}

This experiment was carried out at the Animal House of the Bioresources Development Centre, Isanlu, Kogi State, Nigeria. The rabbits were housed individually in separate hutches measuring $60 \mathrm{~cm} \times 45 \mathrm{~cm} \times 45 \mathrm{~cm}$ under controlled light cycle ( $12 \mathrm{~h}$ light/12 h dark). After a 7 -day acclimatization period, 72 crossbred rabbits with a weight range of 715 and $725 \mathrm{~g}$ were allotted on a weight equalization basis to 4 treatment groups. Eighteen male rabbits each were allotted to 4 treatment groups; with 0 , 500,750 and $1250 \mathrm{mg}$ PTRSE per liter $(\mathrm{mg} / \mathrm{L})$ in drinking water per day in a completely randomized design. The extract concentration used in the current study were based on the reports of Okolo et al. (2017) who established that no mortality or toxic signs occurred in Sprague Dawley rats orally administered $50-5000 \mathrm{mg} / \mathrm{kg}$ BW of Pleuroteus tuber regium. The required amount of concentrated PTRSE was measured and reconstituted in appropriate volume. Fresh reconstituted drinking water was offered in a pottery on a daily basis to the rabbits. Throughout the 60-day experimental period, the animals were maintained 
on concentrate ration which was formulated to meet the nutrient requirement of growing rabbits (Table 1). Rabbits were fed ad libitum.

Table 1: Ingredient and nutrient composition of the diet.

\begin{tabular}{|c|c|}
\hline Items & $(\mathrm{g} / \mathrm{kg})$ \\
\hline Maize offal & 100.0 \\
\hline Maize & 310.0 \\
\hline Full fat Soya & 100.0 \\
\hline Groundnut cake & 50.0 \\
\hline Wheat offal & 300.0 \\
\hline Rice husk & 100.0 \\
\hline Oyster shell & 10.0 \\
\hline Bone meal & 20.0 \\
\hline Premix & 5.0 \\
\hline Salt & 5.0 \\
\hline Total & 1000 \\
\hline \multicolumn{2}{|c|}{ Proximate composition (\% Dry matter) } \\
\hline Crude protein & 15.3 \\
\hline Crude fat & 5.14 \\
\hline Crude fibre & 12.5 \\
\hline Calcium & 0.01 \\
\hline \multicolumn{2}{|c|}{$\begin{array}{l}\text { Premix composition per } \mathrm{Kg} \text { diet: vit } \mathrm{A}: 4000000 \mathrm{IU} \text {, vit } \mathrm{D} \text { : } \\
800000 \mathrm{IU} \text {, vit } \mathrm{E}: 40000 \mathrm{mg} \text {, vit } \mathrm{K}_{3}: 800 \mathrm{mg} \text {, vit } \mathrm{B}_{1}: 1000 \mathrm{mg} \text {, vit } \\
\mathrm{B}_{2}: 6000 \mathrm{mg} \text {, vit } \mathrm{B}_{6}: 5000 \mathrm{mg} \text {, vit } \mathrm{B}_{12}: 25 \mathrm{mg} \text {, Niacin: } 6000 \mathrm{mg} \text {, } \\
\text { Panthothenic acid: } 2000 \mathrm{mg} \text {, Folic acid: } 200 \mathrm{mg} \text {, Biotin: } 8 \mathrm{mg} \text {, } \\
\text { Manganese: } 300000 \mathrm{mg} \text {, Iron: } 8000 \mathrm{mg} \text {, Zinc: } 20000 \mathrm{mg} \text {, Cobalt: } \\
\text { 80mg, Iodine: } 400 \mathrm{mg} \text {, Selenium: } 40 \mathrm{mg} \text {, Choline: } 800000 \mathrm{mg} \text {. }\end{array}$} \\
\hline
\end{tabular}

\section{Data COLlection}

Data was collected on feed intake per pen daily, weight monitored weekly, and mortality records kept. The leftover water was measured the next morning to determine the water and extract intake.

\section{BLOOD COLLECTION AND SERUM CHEMISTRY ANALYSES}

On day 60 of the experiment, blood was collected from the ear and/or lateral saphenous veins of 9 rabbits per treatment (36 rabbits in all) for serum biochemical analyses. The activities of alkaline phosphatase (ALP), total protein, albumin, total cholesterol, triglycerides high-density lipoprotein (HDL), low-density lipoprotein (LDL), very-low-density lipoprotein (VLDL), aspartate aminotransferase (AST), alanine aminotransferase (ALT), creatinine and blood urea nitrogen (BUN) were determined according to the methods described by Reitman and Frankel (1957). Commercial laboratory test kits (Randox laboratories UK) and a UV Vis Spectrophotometer (721 (D), PEC Medical, USA) was used to carry out these analyses.

\section{Histomorphological parameters}

On the $60^{\text {th }}$ day of the experiment, a total of 24 rabbits comprising 6 rabbits per treatment, were slaughtered after their weights were taken. The heart, stomach, kidney, spleen, and liver of the rabbits were harvested and weighed. The percentage weights of the harvested organs relative to the carcass were determined. Small pieces of the caecum, duodenum, and liver tissues were collected in $10 \%$ formalin buffer for proper fixation. The tissues were embedded in paraffin wax, histological sections of 5-6 $\mu \mathrm{m}$ in thickness were made and stained with hematoxylin and eosin for gut measurements and histopathological examinations.

\section{STATistical AnAlysis}

Data collected were subjected to a one-way analysis of variance (ANOVA) test in a completely randomized design. Statistical analysis was carried out using the SAS version 9.1 software (SAS, 2000). A Duncan, multiple range test was done at $95 \%$ confidence interval to separate statistically significant means. Polynomial contrast (Linear (L), quadratic (Q) and cubic (C)) was also applied to determine the effect of dosage of PTRSE.

\section{RESULTS AND DISCUSSION}

Figure 1 shows the concentration of phytochemicals present in both PTRS powder (PTRSP) and extract (PTRSE). Phytochemicals with antioxidant properties were detected in varying concentrations in both PTRSP and PTRSE. The phytate, tannin, alkaloid, and phenol contents of the extract were higher than those of the powder. However, the flavonoid content of the extract was lower than that of the powder. Cyanide, an important antinutrient was also detected in minute amounts in in both powder and extract.

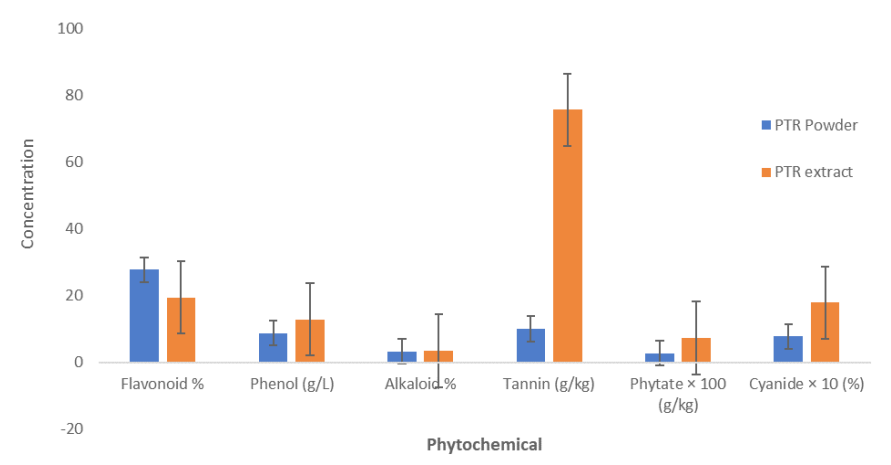

Figure 1: Quantitative assay of the Phytochemical constituents of PTR powder and extract.

Table 2 shows the performance and serum biochemical parameters in the experimental rabbits. The live weight $(\mathrm{P}<0.01)$ and weight gain $(\mathrm{L}, \mathrm{Q}: \mathrm{P}<0.01)$ increased following increasing levels of extract in drinking water. In a similar vein, FCR reduced ( $\mathrm{L}, \mathrm{Q}: \mathrm{P}<0.01)$. The highest values for live weight and weight gain were recorded in rabbits administered $750 \mathrm{mg} / \mathrm{L}$ PTRSE while the least 
values were seen in the control group. Feed intake and FCR in rabbits on $750 \mathrm{mg} / \mathrm{L}$ were similar to those on $1250 \mathrm{mg} / \mathrm{L}$ PTRSE. A corresponding decline in feed intake $(\mathrm{L}: \mathrm{P}<0.05$, $\mathrm{Q}: \mathrm{P}<0.01)$. Followed increasing levels of PTRS extract in drinking water. Water intake $(\mathrm{P}<0.05)$ in rabbits on 500 $\mathrm{mg} / \mathrm{L}$ and $750 \mathrm{mg} / \mathrm{L}$ PTRSE were higher than those of the control group. As the extract's levels in drinking water increased, extract intake increased (L, $\mathrm{Q}: \mathrm{P}<0.01$ ). Percentage mortality in all treatments were less than $5 \%$.

In comparison with the control and other treatment groups, serum albumin concentration was cubically lower $(\mathrm{P}<0.05)$ while globulin was higher $(\mathrm{L}: \mathrm{P}<0.05, \mathrm{Q}: \mathrm{P}<0.01)$ in rabbits on $750 \mathrm{mg} / \mathrm{L}$ PTRSE. Serum total cholesterol in rabbits administered varying levels of extract in drinking water was higher $((\mathrm{L}: \mathrm{P}<0.05, \mathrm{Q}: \mathrm{P}<0.01)$, Triglyceride was quadratically lower $(\mathrm{P}<0.05), \mathrm{HDL}$ and $\mathrm{LDL}$ were higher $(\mathrm{P}<0.01)$ while VLDL was quadratically lower $(\mathrm{P}<0.05)$ than those of the control group. An increase $(\mathrm{L}: \mathrm{P}<0.05$, $\mathrm{Q}: \mathrm{P}<0.01)$ in glucose concentration was observed following increasing levels of extract in drinking water and rabbits on $1250 \mathrm{mg} / \mathrm{L}$ PTRSE had the highest value while the control group had the least. Serum creatinine in rabbits on varying levels of PTRSE was cubically lower $(\mathrm{P}<0.05)$ than those of the control and rabbits on $750 \mathrm{mg} / \mathrm{L} \mathrm{PTRSE}$ had the lowest value. Serum ALT was quadratically lower $(\mathrm{P}<0.01)$ in rabbits on $500 \mathrm{mg} / \mathrm{L}$ while ALP was lowest $(\mathrm{L}, \mathrm{Q}: \mathrm{P}<0.01)$ in rabbits on $750 \mathrm{mg} / \mathrm{L}$ PTRSE when compared to those of control and other treatment groups.

Table 3 shows the relative organ weights and intestinal measurements in growing rabbits orally administered with aqueous extracts of PTRS in drinking water. The relative weight of kidney and cecum were cubically higher $(\mathrm{P}<$ 0.01 ) in T2 while those of small intestine were cubically lower $(\mathrm{P}<0.01)$ in T3 when compared with the control and those allotted to other treatment groups. There were no differences $(P>0.05)$ in the relative weights of liver, spleen, heart, stomach, and duodenum. Cecal weight in rabbits on $750 \mathrm{mg} / \mathrm{L}$ PTRSE was cubically higher $(\mathrm{P}<0.01)$ than those on other treatment groups. Cecal villi height in rabbits on 750 and $1250 \mathrm{mg} / \mathrm{L}$ PTRSE was higher $(\mathrm{L}, \mathrm{Q}: \mathrm{P}<0.05)$ while apical width in rabbits on $750 \mathrm{mg} / \mathrm{L}$ PTRSE was quadratically higher $(\mathrm{P}<0.05)$ than those of the control group. A non-significant $(\mathrm{P}>0.05)$ increase in duodenal villi height was also observed following increasing levels of extracts in drinking water.

Table 2: Performance characteristics and serum biochemical measurements in experimental rabbits administered varying levels of PTRSE in drinking water.

\begin{tabular}{|c|c|c|c|c|c|c|c|c|}
\hline & \multicolumn{4}{|c|}{ Amount of PTRSE in drinking water in $\mathrm{mg} / \mathrm{L}$} & \multicolumn{4}{|c|}{ Probability } \\
\hline Parameter & 0 & 500 & 750 & 1250 & SEM & Linear & Quadratic & Cubic \\
\hline Initial weight (g/rabbit) & 718.03 & 725.09 & 725.29 & 721.56 & 1.71 & NS & NS & NS \\
\hline Final live weight ( $\mathrm{g} / \mathrm{rabbit})$ & $1284.33^{\mathrm{d}}$ & $1562.14^{\mathrm{c}}$ & $1810.75^{\mathrm{a}}$ & $1723.16^{\mathrm{b}}$ & 42.55 & $* *$ & NS & ** \\
\hline weight gain (g/rabbit/day) & $9.44^{\mathrm{d}}$ & $13.95^{\mathrm{c}}$ & $18.09^{a}$ & $16.69^{b}$ & 0.70 & $* *$ & ** & $* *$ \\
\hline Feed intake (g/rabbit/day) & $71.17^{a}$ & $67.08^{a b}$ & $64.00^{\mathrm{bc}}$ & $61.41^{b c}$ & 1.03 & ** & $* *$ & $* *$ \\
\hline Feed conversion ratio & $7.54^{\mathrm{a}}$ & $4.81^{\mathrm{b}}$ & $3.54^{c}$ & $3.68^{c}$ & 0.342 & $* *$ & *** & $*$ \\
\hline water intake (mL/rabbit/day) & $157.17^{\mathrm{b}}$ & $193.17^{a}$ & $183.03^{\mathrm{a}}$ & $150.24^{b}$ & 4.88 & ** & NS & NS \\
\hline Extract intake (mg/L/rabbit/day) & $0.000^{\mathrm{d}}$ & $0.086^{c}$ & $0.135^{\mathrm{b}}$ & $0.178^{\mathrm{a}}$ & 0.014 & $* *$ & $* *$ & ** \\
\hline Mortality (\%) & $1.67^{\mathrm{b}}$ & $2.20^{\mathrm{b}}$ & $3.33^{\mathrm{a}}$ & $3.33^{\mathrm{a}}$ & 0.228 & $* *$ & NS & NS \\
\hline Total protein $(\mathrm{g} / \mathrm{dL})$ & 9.02 & 9.13 & 8.75 & 9.09 & 0.12 & NS & NS & NS \\
\hline Albumin $(g / d L)$ & $5.47^{\mathrm{a}}$ & $5.34^{\mathrm{a}}$ & $4.51^{b}$ & $5.72^{\mathrm{a}}$ & 0.14 & NS & NS & $*$ \\
\hline Globulin (g/dL) & $3.46^{\mathrm{b}}$ & $3.79^{\mathrm{ab}}$ & $4.24^{\mathrm{a}}$ & $3.38^{b}$ & 0.12 & $*$ & * & * \\
\hline Total cholesterol (mg/dL) & $52.91^{\mathrm{c}}$ & $93.07^{\mathrm{a}}$ & $66.36^{\mathrm{b}}$ & $62.56^{\mathrm{bc}}$ & 3.48 & $* *$ & $*$ & $* *$ \\
\hline Triglyceride (mg/dL) & $79.42^{a}$ & $62.20^{\mathrm{b}}$ & $66.13^{\mathrm{b}}$ & $61.89^{b}$ & 2.08 & NS & $*$ & $* *$ \\
\hline High density lipoprotein (mg/dL) & $26.85^{\mathrm{c}}$ & $52.84^{\mathrm{a}}$ & $38.73^{\mathrm{b}}$ & $35.11^{\mathrm{b}}$ & 2.35 & $* *$ & NS & ** \\
\hline Low density lipoprotein (mg/dL) & $10.18^{c}$ & $27.79^{a}$ & $14.40^{\mathrm{b}}$ & $15.07^{\mathrm{b}}$ & 1.41 & $* *$ & ** & $* *$ \\
\hline Very low density lipoprotein $(\mathrm{mg} / \mathrm{dL})$ & $15.88^{\mathrm{a}}$ & $12.44^{\mathrm{b}}$ & $13.23^{\mathrm{b}}$ & $12.38^{\mathrm{b}}$ & 0.42 & NS & $*$ & $* *$ \\
\hline Glucose $(\mathrm{mg} / \mathrm{dL})$ & $117.36^{b}$ & $120.20^{\mathrm{b}}$ & $123.7^{\mathrm{b}}$ & $138.40^{\mathrm{a}}$ & 2.09 & $* *$ & $*$ & NS \\
\hline Creatinine $(\mathrm{mg} / \mathrm{dL})$ & $1.18^{\mathrm{a}}$ & $0.853^{\mathrm{ab}}$ & $0.66^{\mathrm{b}}$ & $1.14^{\mathrm{ab}}$ & 0.09 & NS & $*$ & NS \\
\hline Aspartate transaminase (IU/L) & 52.07 & 51.87 & 50.04 & 51.29 & 0.79 & NS & NS & NS \\
\hline Alanine amino transferase (IU/L) & $49.67^{a}$ & $37.87^{\mathrm{b}}$ & $44.89^{\mathrm{a}}$ & $44.89^{a}$ & 1.30 & NS & $* *$ & * \\
\hline Alkaline phosphatase (IU/L) & $73.58^{\mathrm{a}}$ & $68.67^{\mathrm{a}}$ & $58.53^{\mathrm{b}}$ & $70.27^{a}$ & 1.79 & $* *$ & ** & $*$ \\
\hline
\end{tabular}

${ }^{a-d}$ Means along the same row with different superscripts are significantly different at $\mathrm{P}<0.05$ and $\mathrm{P}<0.01$. ${ }^{*} \mathrm{P}<0.05$ ** $\mathrm{P}<0.01 \mathrm{NS}$ not significant. 
Table 3: Organ relative weights and intestinal histomorphometry measurements in rabbits administered varying levels of PTRSE in drinking water.

\begin{tabular}{|c|c|c|c|c|c|c|c|c|}
\hline \multirow[b]{2}{*}{ Parameter } & \multicolumn{4}{|c|}{ Amount of PTRSE in drinking water in $\mathrm{mg} / \mathrm{L}$} & \multicolumn{4}{|c|}{ Probability } \\
\hline & 0 & 500 & 750 & 1250 & SEM & Linear & Quadratic & Cubic \\
\hline Liveweight (g) & $1163.20^{\mathrm{ab}}$ & $1035.45^{\mathrm{b}}$ & $1254.05^{\mathrm{a}}$ & $1059.45^{\mathrm{b}}$ & 32.66 & NS & NS & NS \\
\hline \multicolumn{9}{|c|}{ Organ weights (\% of live weight) } \\
\hline Kidney (\%) & $0.60^{\mathrm{b}}$ & $0.69^{\mathrm{a}}$ & $0.58^{\mathrm{b}}$ & $0.65^{\mathrm{ab}}$ & 0.02 & NS & NS & $*$ \\
\hline Liver (\%) & $3.41^{\mathrm{ab}}$ & $3.36^{\mathrm{ab}}$ & $3.76^{\mathrm{a}}$ & $2.51^{\mathrm{b}}$ & 0.19 & NS & NS & NS \\
\hline Spleen (\%) & 0.04 & 0.04 & 0.04 & 0.05 & 0.002 & NS & NS & NS \\
\hline Heart (\%) & 0.25 & 0.25 & 0.27 & 0.25 & 0.007 & NS & NS & NS \\
\hline Stomach (\%) & 2.50 & 3.81 & 2.50 & 2.83 & 0.30 & NS & NS & NS \\
\hline Duodenum (\%) & 2.39 & 1.77 & 1.94 & 2.00 & 0.15 & NS & NS & NS \\
\hline Small intestine (\%) & $1.66 \mathrm{a}$ & $0.97^{\mathrm{b}}$ & $2.31^{\mathrm{a}}$ & $1.83^{\mathrm{a}}$ & 0.17 & NS & NS & $* *$ \\
\hline Caecum (\%) & $7.82^{\mathrm{bc}}$ & $6.19^{c}$ & $10.00^{a}$ & $7.82^{\mathrm{bc}}$ & 0.50 & NS & NS & $* *$ \\
\hline \multicolumn{9}{|l|}{ Caecum } \\
\hline Villi height $(\mu \mathrm{m})$ & $700.00^{\mathrm{b}}$ & $625.00^{\mathrm{b}}$ & $990.00^{a}$ & $1100.00^{\mathrm{a}}$ & 61.65 & $* *$ & $*$ & $* *$ \\
\hline Apical width $(\mu \mathrm{m})$ & $70.00^{\mathrm{b}}$ & $70.00^{\mathrm{b}}$ & $100.00^{\mathrm{a}}$ & $50.00^{\mathrm{b}}$ & 6.53 & NS & $*$ & $*$ \\
\hline Basal width $(\mu \mathrm{m})$ & 250.00 & 200.00 & 215.00 & 200.00 & 8.90 & NS & NS & NS \\
\hline Laminal propial depth $(\mu \mathrm{m})$ & 50.00 & 40.00 & 40.00 & 40.00 & 2.18 & NS & NS & NS \\
\hline \multicolumn{9}{|l|}{ Duodenum } \\
\hline Villi height $(\mu \mathrm{m})$ & 400.00 & 410.00 & 450.00 & 500.00 & 27.74 & NS & NS & NS \\
\hline Apical width $(\mu \mathrm{m})$ & 35.00 & 30.00 & 35.00 & 35.00 & 11.25 & NS & NS & NS \\
\hline Basal width $(\mu \mathrm{m})$ & 70.00 & 60.00 & 75.00 & 70.00 & 4.09 & NS & NS & NS \\
\hline Laminal propial depth $(\mu \mathrm{m})$ & 45.00 & 50.00 & 40.00 & 55.00 & 4.15 & NS & NS & NS \\
\hline
\end{tabular}

${ }^{a-c}$ Means along the same row with different superscripts are significantly different at $\mathrm{P}<0.05$ and $\mathrm{P}<0.01{ }^{*} \mathrm{P}<0.05 * * \mathrm{P}<0.01 \mathrm{NS}$ not significant.

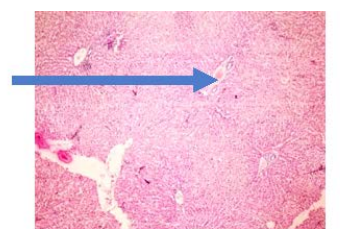

$\mathrm{x} 40$

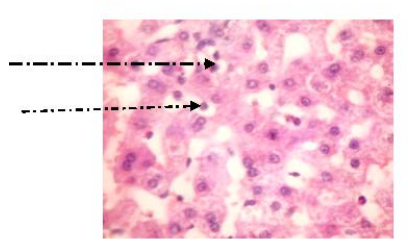

$\mathrm{x} 400$

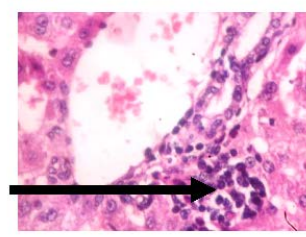

$\mathrm{x} 400$

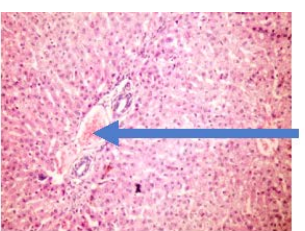

$\mathrm{x} 100$

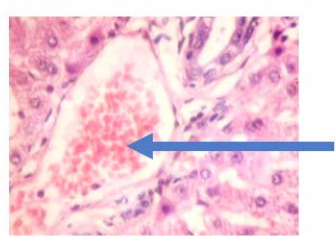

$\mathrm{x} 400$

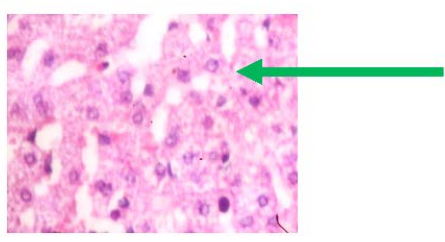

$\mathrm{x} 400$

Figure 2: Liver plates in rabbits on $0 \mathrm{mg} / \mathrm{L}$ PTRSE in drinking water. Liver plates show mild to moderate disseminated microvesicular steatosis (green arrows), congestion (blue arrows), mild periportal infiltration by inflammatory cells (black arrows) and mild infiltration of zone 2 by inflammatory cells (dotted arrow).

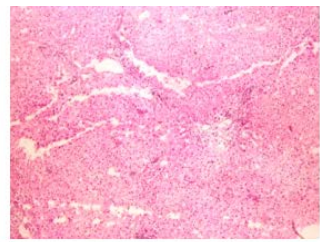

$\mathrm{X} 40$

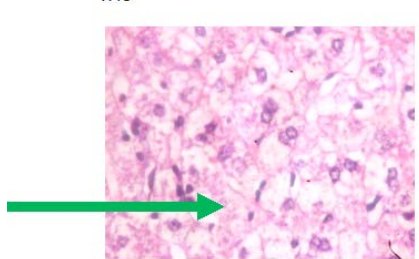

$\mathrm{X} 400$

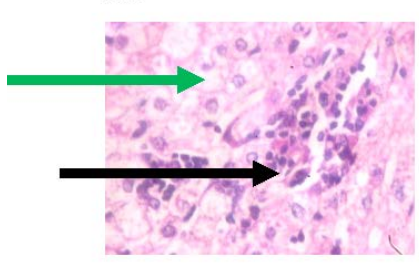

$\times 400$

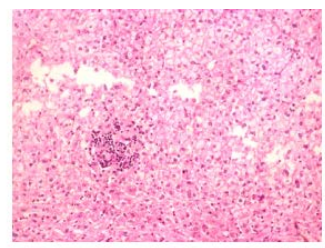

$\mathrm{x} 100$

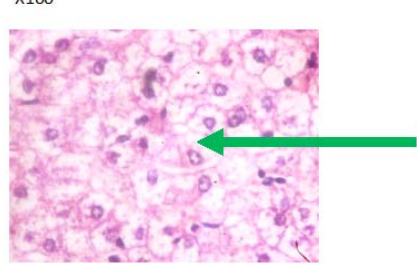

$\mathrm{X} 400$

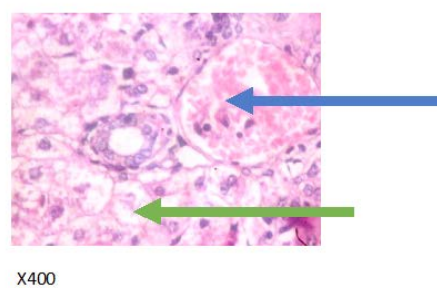

Figure 3: Liver plates in rabbits on $500 \mathrm{mg} / \mathrm{L}$ PTRSE in drinking water. Liver plates show marked to severe disseminated microvesicular steatosis (green arrows), mild periportal steatosis (black arrows) and focal congestion (blue arrows). 
The experimental rabbits showed signs of non-alcoholic fatty liver disease (NAFLD) as seen with the different degrees of micro vesicular steatosis observed in rabbits on 0, 500, and $750 \mathrm{mg} / \mathrm{L}$ PTRSE (Figures 2, 3, 4, 5). Pathology indicators suggest the worst liver tissue damage occurred in rabbits on $1250 \mathrm{mg} / \mathrm{L}$ (Figure 5) and the least occurred in those on $750 \mathrm{mg} / \mathrm{L}$ PTRSE (Figure 3). The histopathological evaluation of the hepatic tissue samples was based on the pattern and severity of the injury. There are no necrotic zones, necroinflammation, cholestatic patterns of liver injury in all the groups. However, a focal area of hemorrhagic lesion was seen in rabbits on 1250 mg/L PTRSE (Figure 5).

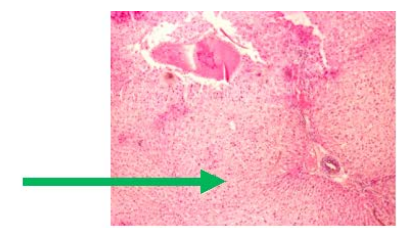

$\mathrm{x} 40$

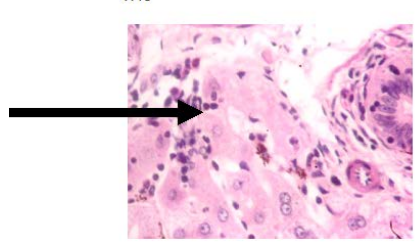

$\mathrm{x} 400$

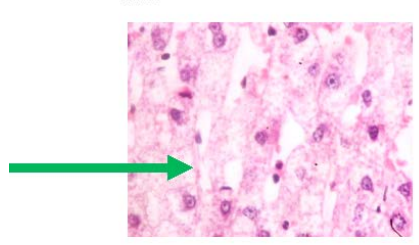

$\mathrm{X} 400$

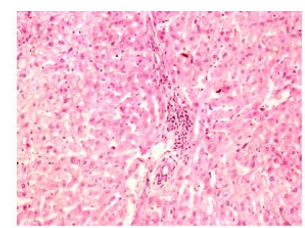

$\mathrm{x} 100$

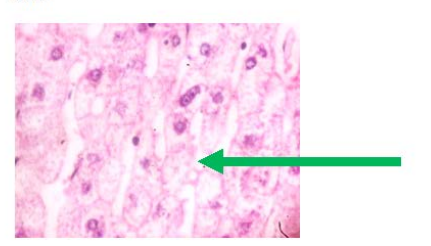

$\times 400$

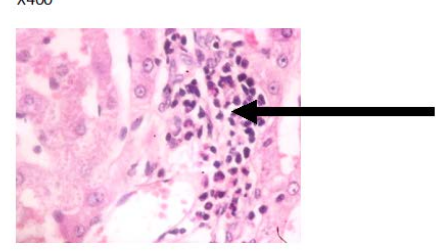

$\mathrm{x} 400$

Figure 4: Liver plates in rabbits on $750 \mathrm{mg} / \mathrm{L}$ PTRSE in drinking water. Liver plates shows moderate to marked disseminated microvesicular steatosis (green arrows) and focal area of periportal infiltration by inflammatory cells (black arrows).

Higher phytochemical contents found in PTRSE in comparison to PTRSP is an indication that hot water extraction resulted in the optimization of the concentrations of these bioactive compounds. This in line with the reports of Jo et al. (2017). Lower flavonoid content in PTRSE is an indication that hot water extraction may have led to the degradation of this phytochemical. This observation agrees with the reports of Elhamirad and Zamanipoor (2012) who found that many antioxidants exhibiting high preventive activity at storage temperatures, rapidly break down and lose their effectiveness when exposed to elevated temperatures. Therefore, for optimization of flavonoid extraction, other formal extraction methods that do not involve elevated temperature should be explored. Antinutrients (tannin, cyanide and phytate) detected in both powder and extract occurred at minimal dose considered to be non- toxic to the rabbits.

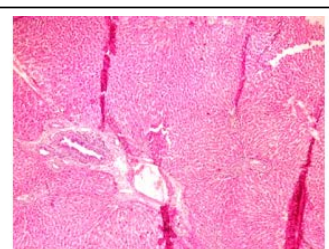

$\mathrm{x} 40$

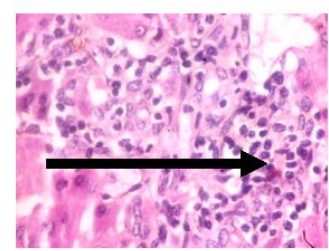

$\mathrm{x} 400$

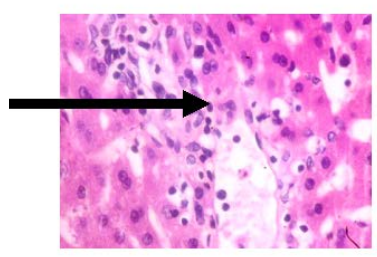

$\mathrm{x} 400$ $\mathrm{x} 100$

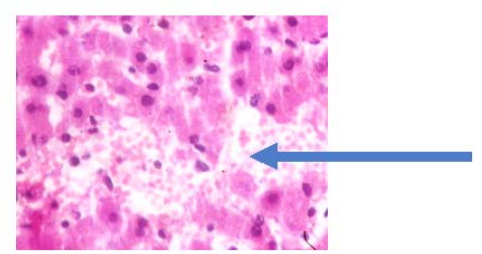

$\times 400$

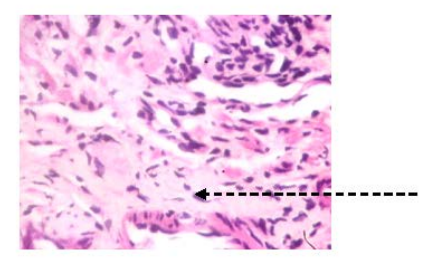

$\mathrm{x} 400$

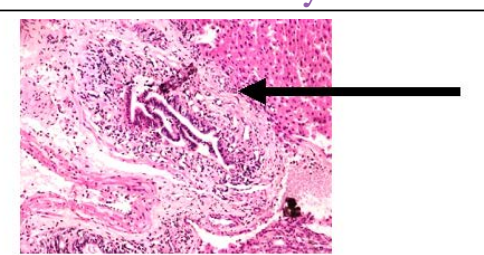

Figure 5: Liver plates in rabbits on $1250 \mathrm{mg} / \mathrm{L}$ PTRSE in drinking. Liver plates show periportal infiltration by inflammatory cells (black arrows), portal fibrosis (dotted arrow) and focal area of hemorrhagic lesion (blue arrows).

The improved growth found in rabbits on PTRSE compared to control agrees with the report of Guo et al. (2004) who showed that mushroom extract increases body weight gain and lowers FCR in broilers. Decline in feed intake amongst rabbits administered PTRSE suggest that PTRSE is an appetite suppressant in agreement with the result of Hess et al. (2017) who found that mushroom extract increased satiety and reduced prospective food intake in human subjects. The opposite trend in water intake against declining FCR seen in rabbits on PTRSE is similar to the observations of Chikumba and Chimonyo (2014) in chickens. Percentage mortality in all rabbits were less than $5 \%$ and increases in hepatic enzymes were not reflected. This indicates that PTRSE (up to $1250 \mathrm{mg} / \mathrm{l}$ ) do not impose detrimental effects on the rabbits. This observation is in sync with the reports of Okolo et al. (2017) in rats orally administered $50-5000 \mathrm{mg} / \mathrm{kg}$ b.w of Pleuroteus tuber regium.

Improved cholesterol metabolism seen in rabbits administered PTRSE contrasts with the results of Ijeh et al. (2009). The author found that dietary incorporation of PTR at 5 and $10 \%$ had no significant hypolipidemic effects in albino mice. These differences in observations may be due to differences in the mode and route of administering the PTRSE. In the former study PTRSP was incorporated into diet while extract was added to water in the current study. This observation suggest that the extraction of the whole plant and the route of administration (via drinking water) led to the release of more bioavailable phytochemicals, 
consequently improving cholesterol metabolism. Reduced serum enzyme concentration on PTRSE administration to rabbits suggests that increasing levels of extract in drinking water did not cause any injury to the growing rabbit's tissue. Most values were not higher than those of the control and were within the range previously reported for normal rabbits $(1.78-9.8 \mathrm{mmol} / 1$ for AST, $1.4-16.6$ $\mathrm{mmol} / 1$ for creatinine, 0-10.0 IU/1 for ALT, and 4-20 IU/L for ALP (Harcourt-brown, 2002; Archetti et al., 2008). These results suggests that the dosage of PTRSE used in the current study is not harmful to the liver.

Relative weight in most of the visceral organs among rabbits on varying levels of PTRSE and control suggest there was no hepatic injury and this corresponds with the liver enzymes result earlier reported in the current study. The highest cecal weight in rabbits on $750 \mathrm{mg} / \mathrm{L}$ PTRSE is an indicator of improved feed motility and digestibility (Hulls et al., 2016). Increasing values of villi height and apical width observed in this study indicate that increasing levels of PTRSE in drinking water of growing rabbits enhances the intestinal absorptive surface and this corresponds to greater absorption of available nutrients and improved growth (Yasar and Forbes, 1999; Panda et al., 2015).

Microvesicular steatosis of the liver is the accumulation of many small fat vesicles in the hepatocytes without displacing their nuclei. It has been associated with heterogenous causes including drug toxicity, increased alcohol consumption, and Nonalcoholic Fatty Liver Disease (NAFLD) (Hautekeete et al., 1990; Tandra et al., 2011). The microvesicular steatosis observed in rabbits administered with different doses of PTRSE and the control was at varying degrees in a manner that is not dosedependent suggesting that it was not caused by the toxicity of PTRSE. Insufficient exercise in caged rabbits may lead to hypercholesterolemia and subsequently NAFLD (Eung et al., 2014). The presence of microvesicular steatosis in greater than $5 \%$ of the cells of this rabbits also confirms the NAFLD diagnosis (Nguyen and Feldstein, 2021).

In the experimental rabbits, untreated NAFLD seemed to progress into Non-alcoholic steatohepatitis (NASH). The NASH is characterized by periportal inflammation as seen in rabbits administered; 0,750 and $1250 \mathrm{mg} / \mathrm{L}$ PTRSE, lobular inflammation as seen in control; hepatic injury and portal fibrosis as seen in rabbits on $1250 \mathrm{mg} /$ $\mathrm{kg}$ and congestion as seen in both control and rabbits on 500mg/L PTRSE (Wanless and Shiota, 2004; Brunt and Tiniakos, 2010). The sub clinical manifestation of the histopathological features of the different necroinflammatory grades of NASH in treated rabbits is independent of the dose of PTSE administered. The focal area of hemorrhagic lesion seen in rabbits administered with $1250 \mathrm{mg} / \mathrm{L}$ PTRSE could also be a sign of Druginduced liver injury (DILI) but further investigation is required since the level of hepatic enzymes does not suggest so (Kleiner, 2017).

\section{CONCLUSIONS AND RECOMMENDATIONS}

From the findings of the current study, It can be concluded that the oral administration of the aqueous extract of Pleuroteus tuber-regium up to of $750 \mathrm{mg} / \mathrm{L}$ of drinking water can improve the growth, cholesterol profile and nutrient absorptive capacity of growing rabbits without imposing any detrimental effect.

\section{ACKNOWLEDGEMENTS}

The authors are grateful for the support of the Management of Bioresources Development Centre, Isanlu, Kogi State Nigeria for providing the resources needed for this research work.

\section{NOVELTY STATEMENT}

The present study examined the growth promoting potential of the aqeous extract of Pleuroteus tuberregium sclerotia and its effect on histomorphological measurements in growing rabbits.

\section{AUTHOR'S CONTRIBUTION}

All authors contributed to the study conception and design. Material preparation, data collection and analysis were performed by Suliat Salami, Samuel Ogoina, Amos Ayuba, Terna David, Titilayo Asala, Adekunle Rowaiye and Dorfan Bur. The first draft of the manuscript was written by Suliat Salami and all authors commented on previous versions of the manuscript. All authors read and approved the final manuscript.

\section{CONFLICT OF INTEREST}

The authors have declared no conflict of interest.

\section{ETHICS APPROVAL}

All procedures performed in this study were done following the institution's ethical standards or practice at which the studies were conducted. The experiment was performed in accordance with the ethical standards laid down in the 1964 Declaration of Helsinki and its later amendments.

\section{REFERENCES}

-Archetti I, Tittarelli C, Cerioli M, Brivio R, Grilli G, Lavazza 
A (2008). Serum chemistry and hematology values in commercial rabbits: preliminary data from industrial farms in northern Italy. Proc. $9^{\text {th }}$ World Rabbit Cong., Verona, Italy, pp. 1147-1152.

-Asif A, Muhammad K (2018). $\beta$-Glucan as a food ingredient. In: Grumezescu, A.M. and Holban, A.M. ed Academic press London, pp. 351-381. https://doi.org/10.1016/B9780-12-811449-0.00011-6

-Aziz RA, Sarmidi MR, Kumaresan S (2003). Phytochemical processing: The next emerging field in chemical engineering aspects and opportunities Jabatan Kejuruteraan Kimia dan Proses, Universitas Kebangsaan, Malaysia, 45-60.

-Brunt EM and Tiniakos, DG (2010). Histopathology of nonalcoholic fatty liver disease. World J. Gastroenterol., 16(42): 5286-5296. https://doi.org/10.3748/wjg.v16. i42.5286

- Chikumba N, Chimonyo M (2014). Effects of water restriction on the growth performance, carcass characteristics and organ weights of naked neck and ovambo chickens of southern Africa. Asian-Australas. J. Anim. Sci., 27(7): 974980. https://doi.org/10.5713/ajas.2013.13383

- Elhamirad AH, Zamanipoor MH (2012). Thermal stability of some flavonoids and phenolic acids in sheep tallow olein. Eur. J. Lipid Sci. Tech., 114(5): 602-606. https://doi. org/10.1002/ejlt.201100240

-Eung JK, Baek-hui K, Hong SS, Yong JL, Hyun HK, HyunHwa S, Man HC (2014). Cholesterol induced nonalcoholic fatty liver disease and atherosclerosis aggravated by systemic inflammation. PLoS One, 9(6): e97841. https:// doi.org/10.1371/journal.pone.0097841

- Guo FC, Kwakkel RP, Williams BA, Li WK, Li HS, Luo JY, Li XP, Wei YX, Yan ZT, Verstegen MW (2004). Effects of mushroom and herb polysaccharides, as alternatives for an antibiotic, on growth performance of broilers. Br. Poult. Sci., 45(5): 684-694. https://doi. org/10.1080/00071660400006214

- Harborne JB (1984). Methods of plant analysis. In: Phytochemical Methods. Springer, Dordrecht. https://doi. org/10.1007/978-94-009-5570-7

- Harcourt-Brown F (2002). The textbook of rabbit medicine, $4^{\text {th }}$ edition, Butterworth Heinemann Education, pp. 28-30.

-Hautekeete ML,Degott C,Benhamou JP(1990). Microvesicular steatosis of the liver. Acta Clin Belg. 45(5): 311-126. https:// doi.org/10.1080/17843286.1990.11718105

- Hayouni M, Abedrabba M, Bouix MH (2007). The effects of solvents and extraction method on the phenolic contents and biological activities in vitro of Tunisian Quercus coccifera L. and Juniperus phoenica L. fruit extracts. Food Chem., 105: 1126-1134. https://doi.org/10.1016/j. foodchem.2007.02.010

- Helmja K, Vaher M, Gorbatsova J, Kaljurand M (2007). Characterization of bioactive compounds contained in vegetables of the Solanaceae family by capillary electrophoresis. Proc. Estonian Acad. Sci. Chem., 56: 172186.

-Hess, JM, Qi WC, Kraft J, Slavin L (2017). Impact of Agaricus bisporus mushroom consumption on satiety and food intake. Appetite, 117(1): 179-185. https://doi.org/10.1016/j. appet.2017.06.021

-Huang HY, Korivi M, Yang HT, Huang CC, Chaing YY, Tsai YC (2014). Effect of Pleurotus tuber-regium polysaccharides supplementation on the progression of diabetes complications in obese diabetic rats. Chin. J. Physiol., 57(4):
198-208. https://doi.org/10.4077/CJP.2014.BAC245

- Hulls C, Lentle RG, Reynolds GW, Patrick W, Janssen M, Chambers P, de Loubens C (2016). Ex vivo motility in the base of the rabbit caecum and its associated structures: An electrophysiological and spatiotemporal analysis. J. Physiol. Biochem., 72: 45-57. https://doi.org/10.1007/s13105-0150455-3

- Ijeh II, Okwujiako IA, Nwosu PC, Nnodim HI (2009). Phytochemical composition of Pleurotus tuber regium and effect of its dietary incorporation on body /organ weights and serum triacylglycerols in albino mice. J. Med. Plant Res., 3(11): 939-943.

-Jo I, Kim S, Min B, Jung H, Han Y, Kim J (2017). Optimization of hot-water extraction conditions of bioactive compounds from coffee residue extracts. Korean J. Chem. Eng., 55(3): 358-362.

-Jyotika V, Jot HO, Bhushan MJ, Istvan A, Jenny F, Rhond LS, Andrew DP, Marghereta TC (2013). White button mushrooms increase microbial diversity and accelerate the resolution of Citrobacter rotentium infection in mice.J. Nutr., 143(4): 526-532. https://doi.org/10.3945/jn.112.171355

-Kleiner DE (2017). Histopathological challenges in suspected drug-induced liver injury. Liver Int., 38(2): 198-209. https:// doi.org/10.1111/liv.13584

- Makkar HP, Blummel SM, Borowy NK, Becker K (1993). Gravimetric determination of tannins and their correlations with chemical and protein precipitation methods. J. Sci. Food Agric., 61: 161-165. https://doi.org/10.1002/ jsfa.2740610205

-Malick CP, Singh MB (1980). Plant enzymology and histo-enzymology. $4^{\text {th }}$ ed. Kalyani Publishers, New Delhi, 278.

- Nguyen V, Feldstein AE (2021). Nonalcoholic Fatty Liver Disease, Editor(s): Robert Wyllie, Jeffrey S. Hyams, Marsha Kay, Pediatric Gastrointestinal and Liver Disease (Sixth Edition), Elsevier publishers UK, pp. 812-818. https://doi. org/10.1016/B978-0-323-67293-1.00074-8

- Nworu CS, Ihim SA, Okoye FB, Esimone CO, Adikwu MU, Akah PA (2014). Immunomodulatory and immunorestorative activities of $\beta-\mathrm{d}$-glucan-rich extract and polysaccharide fraction of mushroom, Pleurutus tuberregium. J. Pharm. Biol., 53(11): 1555-1566. https://doi.org/10.3109 /13880209.2014.991838

- Oghenemaro EF (2017). Effect of aqueous and ethanol extracts of Pleurotus tuber regium on the haematological indices of albino wistar rats. J. Pharm. Res. Allied Sci., 14(5).

-Okolo KO, Orisakwe OE, Siminialay IM (2017). Pleurotus tuber-regium mushrooms in the diet of rats ameliorates reproductive and testicular injury caused by carbon tetrachloride. Clin. Phytoscience, 3: 14-24. https://doi. org/10.1186/s40816-017-0051-x

- Oyetayo O (2011). Medicinal uses of mushrooms in Nigeria: towards full and sustainable exploitation. Afri. J. Tradit. Complem. Altern. Med., 8(3): 267-274. https://doi. org/10.4314/ajtcam.v8i3.65289

-Panda AK, Bhanja SK, Sunder G (2015). Early post hatch nutrition on immune system development and function in broiler chickens. World Poult. Sci. J., 71(2): 285-296. https://doi.org/10.1017/S004393391500029X

-Poonam GD, Appasaheb A, Ghadge SB, Tannaz JB (2011). Preparation of decoction of medicinal plants: A self-help measure. J. Altern. Complemen. Med., 17(12): 1099-1100. https://doi.org/10.1089/acm.2011.0217 
- Reitman S, Frankel S (1957). A colorimetric method for the determination of serum glutamic oxalacetic and glutamic pyruvic transaminases. Am. J. Clin. Pathol., 128(1): 56-63. https://doi.org/10.1093/ajcp/28.1.56

- Sethiya NK (2016). Review on natural growth promoters available for improving gut health of poultry: An alternative to antibiotic growth promoters. Asian J. Poult. Sci., 10: 1-29. https://doi.org/10.3923/ajpsaj.2016.1.29

- Sohail HK, Nasir M, Javid I (2019). Role of mushroom as dietary supplement on performance of poultry. J. Diet Suppl. 16(5): 611-624. https://doi.org/10.1080/19390211.2018.1472707

- System of Analytical and statistical software, SAS (2000). SAS Users Guide; Version 9.1 revised edition, SAS Institute Inc, Carry, NC.

-Tandra S, Yeh, MM. Brunt EM, Vuppalanchi R, Cummings OW, Ünalp-Arida A, Wilson LA. and Chalasani N (2011). Presence and significance of microvesicular steatosis in nonalcoholic fatty liver disease. J. Hepatol., 55(3): 654-659. https://doi.org/10.1016/j.jhep.2010.11.021

-Vargas-Sánchez RD, Torrescano-Urrutia GR, Ibarra-Arias FJ, Portillo-Loera FJ, Ríos-Rincón JG, Sánchez-Escalante A (2018). Effect of dietary supplementation with Pleurotus ostreatus on growth performance and meat quality of Japanese quail. Livest. Sci., 207: 117-125. https://doi. org/10.1016/j.livsci.2017.11.015.

-Wanless IR, Shiota K (2004). The pathogenesis of nonalcoholic steatohepatitis and other fatty liver diseases: A four-step model including the role of lipid release and hepatic venular obstruction in the progression to cirrhosis. Semin. Liver Dis., 24(1): 99-106. https://doi.org/10.1055/s-2004-823104

- Yasar S, Forbes JM (1999). Performance and gastro-intestinal response of broiler chickens fed on cereal grain-based feeds soaked in water. Br. Poult. Sci., 40: 65-76. https://doi. org/10.1080/00071669987854 